\title{
WHAT HAPPENED TO THE AMENTIFERAE?
}

A symposium was presented under the above title at the 23 rd annual meeting of the American Institute of Biological Sciences held at the University of Minnesota in August, 1972. The symposium was jointly sponsored by the American Society of Plant Taxonomists and the Systematics Section of the Botanical Society of America. The papers that make up this issue of the journal* present the substance of that symposium in more permanent form. Especial thanks are due to William Louis Stern for his efforts in bringing this material to publication.

THE EDITOR

* A contribution by E. C. Abbe, "Flowers and inflorescences of the Amentiferae," originally a part of this symposium, will appear separately in The Botanical Review.

Brittonia 25: 315. October-December, 1973. 